DOI: $10.5800 / G T-2020-11-4-0502$

\title{
THE NEPSKY-1 IMPACT CRATER AND ITS FILL DEPOSITS ON THE BASEMENT ROOF OF THE SIBERIAN PLATFORM
}

\author{
M.I. Gyokche $\oplus^{凶}$, A.V. Plyusnin $\odot$
}

Irkutsk Oil Company LLC, 4 Bolshoy Liteiny Ave, Irkutsk 664007, Russia

\begin{abstract}
In the Earth studies, discoveries and investigations of impact craters buried beneath thick sediments are sporadic so far and may still remain inefficient, unless geophysical surveys of the areas of interest are initiated. Such studies can provide useful data to develop the knowledge about cosmic events of the past geological eras, as well as contribute to industrial development of the areas. It is known that an impact crater is filled with layered deposits that create specific sequences and are generally thicker that deposits outside the crater. We have investigated a Precambrian crater located in the southern part of the Nepa-Botuoba anteclise of the Siberian platform. This impact crater called Nepsky-1 was discovered by seismic surveys using the common depth point method (CDPM). In our study, we used the geological and geophysical deep-drilling data of three wells, including gamma-ray and neutron logs and lithological core descriptions. With reference to the concepts of regional geological conditions, we reconstructed the conditions of sedimentation in the study area based on a comprehensive analysis of the structural and textural features of the rocks, and logging and seismic survey data. By processing and interpretation of the CDPM 3D seismic survey data, we obtained the structural images and cross-sections of the impact crater and analysed the thickness of its fill deposits. The Nepsky-1 crater is a bowl-shaped structure with a rim composed of allogenic breccia. In the area around the crater, fault systems are detected. Based on the core sample analysis, we identified the lithological members of the crater and its rim and described them in detail. Active compensation with lacustrine-delta sediments took place in the Nepa period of the late Vendian. By the end of the Tira time, the crater was completely leveled up. In our study, we obtained the first data on the structure of the crater section of the Vendian deposits. Sedimentation in the study area was controlled by the sea level changes. The main terrigenous productive horizons are confined to sandstones that accumulated during the sea level low stand, and found at the bottoms of the lower and upper Nepa subsuites, as well as at the bottoms of the lower and upper Tira subsuites. It is established that the study area was tectonically active in the late Tira time. As a result, the sediments filling the crater were removed to subaerial conditions, and the edges of the allogenic breccia rim were partially destroyed and formed granite breccia outgrowths observed in the rim's cross-section. We conclude that in the Nepa and Tira times, tectonic vertical movements initiated relatively fast weathering and transportation of the terrigenous material from the adjacent hills into the sedimentation basin. The Nepsky-1 crater gives evidence of meteorite bombing of the Siberian paleocontinent in Precambrian. Finding similar crater structures can be reasonably expected in the study region. Considering the increased thicknesses of crater fill deposits, buried craters are promising potential for discovering oil-source and overlying seal rocks, which is important for petroleum industry.
\end{abstract}

KEYWORDS: impact structure; crater; crystalline basement; seismic data; CDPM 3D; lithology; lake delta; Nepa suite; Tira suite; Vendian; sedimentary cover; Nepa-Botuoba anteclise; Siberian platform

\section{RESEARCH ARTICLE}

Correspondence: Maryana I. Gyokche, gyokche_mi@irkutskoil.ru
Received: April 30, 2020

Revised: June 7, 2020

Accepted: June 10, 2020

FOR CITATION: Gyokche M.I., Plyusnin A.V., 2020. The Nepsky-1 impact crater and its fill deposits on the basement roof of the Siberian platform. Geodynamics \& Tectonophysics 11 (4), 710-721. doi:10.5800/GT-2020-11-4-0502 


\title{
ИМПАКТНЫЙ КРАТЕР НЕПСКИЙ-1 И ОСАДКИ, ВЫПОЛНЯЮЩИЕ ЕГО НА ПОВЕРХНОСТИ ФУНДАМЕНТА СИБИРСКОЙ ПЛАТФОРМЫ
}

\author{
М.И. Гёкче, А.В. Плюснин
}

000 «Иркутская нефтяная компания», 664007, Иркутск, Большой Литейный пр-т, 4, Россия

АннотАция. Обнаружение и изучение импактных кратеров, скрытых под многометровой толщей осадочного чехла, носят спорадический характер и не представляются возможными без использования площадной геофизической сьемки. Их исследование является актуальным, так как может пролить свет на космические события, происходившие в прошлые геологические эпохи. Осадки, заполняющие кратер, создают особый тип разреза с увеличенной мощностью по сравнению с таковыми за пределами кратера. Целью исследования является изучение особенностей погребенного кратера докембрийского возраста, впервые обнаруженного при проведении площадных сейсмических работ МОГТ на юге Непско-Ботуобинской антеклизы Сибирской платформы. В ходе работы авторами были использованы геолого-геофизические данные глубокого бурения трех скважин, включающие гамма-каротаж, нейтронный каротаж, литологическое описание керна. В результате комплексного анализа структурно-текстурных признаков пород, каротажных диаграмм и сейсмических данных, с учетом концепций региональных геологических условий, воссозданы условия осадконакопления в исследуемом районе. Структурные построения, анализ мощности разрезов выполнены на основании данных обработки и интерпретации сейсморазведочных работ методом МОГТ 3D. Кратер имеет чашеобразную форму с насыпным валом аллогенной брекчии. Вокруг кратера фиксируются серии разломов. Результаты исследования керна в районе кратера позволили выделить и детально описать пачки кратерного и бортового типа разреза. В непское время позднего венда происходила его активная компенсация озерно-дельтовыми осадками. К концу тирского времени он был полностью снивелирован. Впервые получены данные о строении кратерного разреза вендских отложений. Формирование отложений контролировалось колебанием уровня моря. К песчаникам, накопившимся в этап низкого стояния уровня моря, приурочены основные терригенные продуктивные горизонты: в подошве нижненепской и верхненепской, а также в подошве нижнетирской и верхнетирской подсвиты. Установлено, что в позднетирское время в регионе произошла тектоническая активизация, которая привела осадки кратера к выводу в субаэральные условия и спровоцировала частичное разрушение выступов аллогенной брекчии, которые сформировали выносы гранитной брекчии в бортовом типе разреза. В непское и тирское время, по мнению авторов, имели место тектонические вертикальные движения, которые инициировали относительно быстрое выветривание и транспортировку терригенного материала с прилегающих возвышенностей в бассейн осадконакопления. Обнаруженный кратер свидетельствует о метеоритных бомбардировках Сибирского палеоконтинента в докембрии. Следует ожидать обнаружение данных структур в исследуемом регионе. Образованные кратеры привлекательны повышенной мощностью отложений, наличием потенциальных нефтематеринских пород и покрышек. Выявление кратеров является перспективной задачей нефтегазовой отрасли.

КЛЮЧЕВЫЕ СЛОВА: импактная структура; кратер; кристаллический фундамент; сейсмические материалы; МоГT 3D; литология; озерная дельта; непская свита; тирская свита; венд; осадочный чехол; Непско-Ботуобинская антеклиза; Сибирская платформа

\section{1. ВВЕДЕНИЕ}

Ударное кратерообразование - один из важнейших факторов формирования поверхности Земли и планет земной группы. В то же время геологическая активность земной коры, атмосферы и гидросферы определяет высокую скорость уничтожения следов метеоритной бомбардировки, в результате которой на поверхности сохранилась только небольшая часть импактных структур преимущественно мезо-кайнозойского возраста [Gurov, Gozhik, 2006].

Обнаружение и изучение таких структур более позднего возраста, скрытых под многометровой толщей осадочного чехла, носят спорадический характер и не представляются возможными без использования площадной геофизической сьемки. Исследование импактных кратеров может пролить свет на космические события, происходившие в прошлые геологические эпохи. Осадки, заполняющие кратер, создают «уникальный» тип разреза с увеличенной мощностью по сравнению с таковыми за пределами кратера. Будучи ослабленной структурой, кратерный тип разреза чувствителен к любым тектоническим активизациям, что находит отражение в строении заполняющих его осадков. Нередко к кратерам приурочены нефтематеринские породы, поэтому их обнаружение и картирование необходимо проводить при изучении нефтегазоносности осадочных бассейнов и проведении геологоразведочных работ [Gurov, 2016; Bacon et al., 2007; Mazur et al., 2000].

В 2013 г. при проведении площадных сейсмических работ МОГТ 2D, а затем в 2014 г. и МОГТ 3D на одном 
из лицензионных участков, находящихся в долине реки Нижняя Тунгуска, на расстоянии 75 км северо-западнее города Киренска Иркутской области, обнаружена чашеобразная структура, позднее диагностированная авторами как импактный кратер. В результате анализа открытых источников информации было установлено, что погребенные кратеры на поверхности фундамента Непско-Ботуобинской антеклизы ранее не были открыты. Кратеру присвоено имя Непский-1 [Plyusnin, Gekche, 2020a].

\section{2. МАТЕРИАЛ И МЕТОДЫ}

В ходе исследований были использованы геологогеофизические данные глубокого бурения трех скважин, включающие гамма-каротаж, нейтронный каротаж, литологическое описание керна. Структурные построения, анализ мощности разрезов выполнены на основании данных обработки и интерпретации сейсморазведочных работ методом МОГТ 3D на площа-

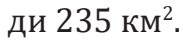

При работе с керновым материалом и интерпретации результатов литологического описания использовались труды [Kuznetsov, 2011; Reinek, Singkh, 1981; Posamentier, Allen, 1999].

\section{3. КРАТКАЯ ГЕОЛОГИЧЕСКАЯ ХАРАКТЕРИСТИКА}

Кратер расположен на южной периклинали НепскоБотуобинской антеклизы (НБА) Сибирской платформы (рис. 1). По положению окружающих и выполняющих кратер осадков время формирования кратера определяется как донепское, когда большая часть юга Сибирской платформы представляла собой денудационную равнину [Belyaev et al., 2009].

Фундамент архей-раннепротерозойского возраста имеет гранитогнейсовый состав. На поверхности фундамента со стратиграфическим несогласием залегают глинисто-песчаные отложения непской свиты непского горизонта, выше перекрывающиеся сульфатно-песчано-глинисто-карбонатными отложениями тирской свиты тирского горизонта. Выше них залегают сульфатно-карбонатно-галогенные отложения венда - кембрия. Осадки, заполняющие разрез кратерного типа, накапливались на протяжении непского и тирского времени позднего венда [Mel'nikov, Repina, 1989; Mel'nikov, 2009; Plyusnin, Gekche, 2020b].

\section{4. ИСТОРИЯ ИЗУЧЕНИЯ КРАТЕРОВ}

Ударное воздействие внеземных тел еще несколько десятилетий назад виделось интересным, но не самым значительным из всех геологических процессов, воздействующих на Землю. Только в начале XX столетия начала образовываться некая доказательная база наличия на Земле воронок от падения внеземных болидов; в 40-50-х годах прошлого столетия, с началом активного применения аэрофотосъемки, стало обнаруживаться достаточно много кольцевидных структур на поверхности планеты - следы ударов космических тел, а поиски и целенаправленные исследования продолжаются в настоящее время и имеют большой потенциал [Fel'dman, Glazovskaya, 2018]. Благодаря множеству исследований космоса и более широкому пониманию планетарных процессов и истории Солнечной системы, стало ясно, что воздействие тел на планеты было доминирующим геологическим и важным геодинамическим процессом во всей ранней Солнечной системе, что доказывается на примере планет и спутников, сохранивших на поверхности рельеф - результат мощных ударных воздействий космических тел, и Земля не является исключением [Glukhovsky, Kuz'$\min , 2015]$.

Несмотря на то, что в земных условиях сохранность кратеров на поверхности была менее вероятна, чем их уничтожение под воздействием различных геологических процессов, таких как эрозия, тектонические активизации и прочие, в наше время насчитывается достаточное количество примеров для изучения. Согласно данным Центра планетных и космических наук Университета Нью-Брансуик [Earth Impact Database, 2018], в настоящий момент официально подтверждено 190 наземных импактных кратеров на пяти континентах.

Наземные ударные структуры традиционно диагностируются по морфологическим признакам (таким, как кольцевой вал вокруг воронки, центральное поднятие, радиально-кольцевое расположение разломов) и находят подтверждение при детальных петрографических исследованиях образцов пород. Но, помимо наземных кратеров, с развитием геофизических методов обнаруживаются и погребенные структуры, которые представляют больший геологический и экономический интерес вследствие благоприятных условий для генерации и формирования залежей углеводородов, а также потенциал наличия прочих полезных ископаемых, например медно-никелевое месторождение Садбери в Канаде, приуроченное к одноименному ударному кратеру [Naldrett, 2003]. Конечно, подземные структуры могут быть диагностированы с определенной долей вероятности, однако с развитием современных сейсмических методов, электро- и магниторазведки, а также с подтверждением данных глубокого бурения скважин все большее количество кольцевидных структур находят свое подтверждение как результат ударного воздействия болидов.

Несмотря на то, что каждый кратер в своем роде уникален, все они имеют ряд общих признаков для их идентификации - морфоструктурные, минералого-петрографические и геофизические. Вследствие специфического процесса их образования, большинство кратеров имеют определенный набор свойств (диагностических признаков) - чашеобразная форма с окружающим кольцевым валом или поднятием, наличие обломков подстилающих пород (аллогенные брекчии), радиальные разрывные нарушения, трещиноватость подстилающих пород, центральное поднятие, присутствие импактитов (пород ударного метаморфизма) [Glukhovsky, Kuz'min, 2015; Gurov, Gozhik, 2006; Mazur et al., 2000]. В зависимости от начальных условий произошедшего 
столкновения - состава тела и подударных пород, скорости и угла падения, размера объекта - образуются различные структуры кратеров, которые можно разделить на три типа: простая чашеобразная, которая формируется при субвертикальных ударах относительно небольшими объектами; сложно построенная, образующаяся при падении крупных тел высокой плотности и характеризующаяся относительно низким отношением глубины к диаметру образовавшегося кратера, центральным поднятием, кольцевым желобом и террасной структурой обрамления, а также кратеры переходного типа [Collins et al., 2005; Tsikalas, Faleide, 2007; Fel'dman, Glazovskaya, 2018].

Исходя из общей статистики [Mikheeva, 2008, 2020] на данный момент зарегистрировано 281 достоверных, 293 вероятных и 2426 предполагаемых импактных структур различных возрастов, размеров и гипсометрического положения. Из диагностированных кратеров более половины (55 \%) имеют диаметр менее 5 км, около $12 \%$ - от 5 до 10 км, 7 \% - от 10 до 15 км и так далее, согласно логнормальному характеру распределения. На данный момент самым крупным и к тому же одним из самых древних (палеопротерозойского возраста $2023 \pm 4$ млн лет, определен U-Pb методом датирования) выявленных ударных кратеров на поверхности Земли является кратер Вредефорт [Wieland et al., 2005]. Обнаружение подобных структур, сохранившихся до настоящего времени, безусловно, является редкостью как со стороны, вероятно, низкой статистики ударов подобного масштаба в истории Земли, так и с точки зрения сохранности таких объектов. Что касается погребенных структур, обнаружение даже сравнительно небольших

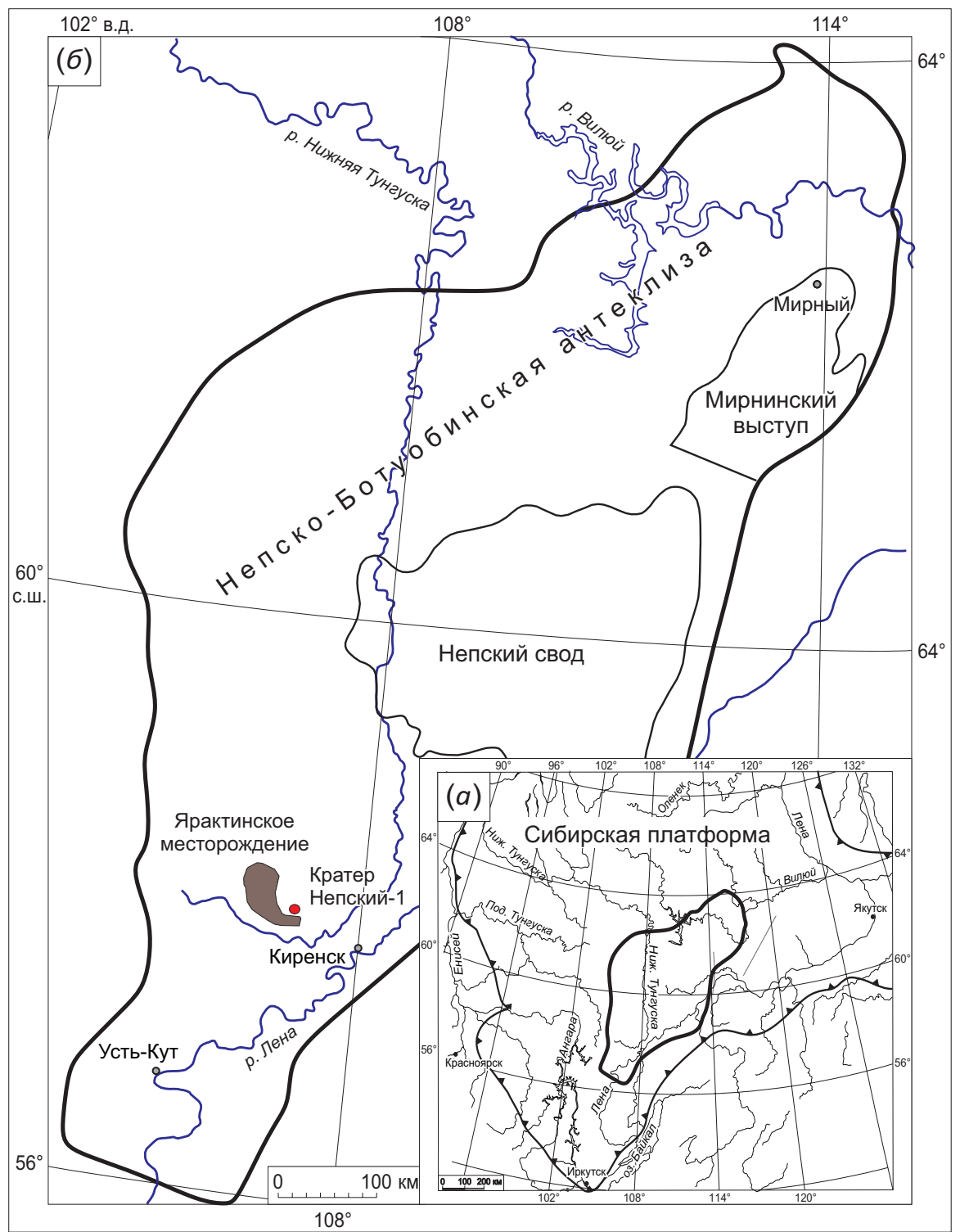

Рис. 1. Район исследований (a) и местоположение кратера Непский-1 (б) на фрагменте тектонической схемы НепскоБотуобинской антеклизы Сибирской платформы по [Tectonic Map ..., 2005] с изменениями авторов.

Fig. 1. Fragment of the tectonic map of the Nepa-Botuoba anteclise, Siberian platform [Tectonic Map ..., 2005]. The authors' data are used to show the study area (a) and the location of the Nepsky-1 crater (б). 
в диаметре кратеров (как, например, кратер Альберта в Канаде, Мускингум в США и объект данной работы кратер Непский-1), а также обоснование их действительности являются серьезной задачей геологии.

\section{5. РЕЗУЛЬТАТ}

Структурно-тектоническая характеристика. Кратер имеет чашеобразную форму диаметром 6 км и глубиной 265 м. Высота цокольного и насыпного вала по юго-восточной стороне составляет 80 м, северо-западной - 30 м (рис. 2). Согласно методике расчета последствий импактного воздействия метеоритов на Землю [Collins et al., 2005], кратер Непский-1, вероятно, образовался вследствие субвертикального удара небесного тела диаметром 300-350 м, средней плотности

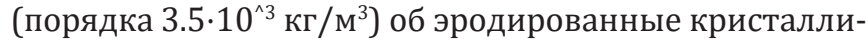
ческие породы фундамента.

Впадина-кратер обрамляется серией разрывных нарушений, в основном сбросового и сдвигового типа. Наиболее яркие и амплитудные разломы наблюдаются с запада, востока и юга от центра кратера, субмеридионального и субширотного простирания соответственно (рис. 3). С южной стороны впадина ограничена контрастным выступом, который представляет собой структуру типа горст амплитудой до 35 м.

Разрывные нарушения на современных сейсмических разрезах трассируются не только в терригенной части разреза, но и вверх по разрезу - по подсолевому и солевому структурным этажам. Основные разломы, вероятно, были заложены совместно с формированием кратера при одновременном воздействии неопротерозойской тектонической активизации, будучи ослабленными зонами, продолжили свое развитие и в периоды последующих геодинамических процессов активизации, происходивших на территории всей НБА (рис. 4).

Литолого-фациальная характеристика. На основе изучения керна скважин авторами приводится описание трех типов разреза, отражающих геодинамические процессы и особенности осадконакопления прошлого в районе кратера: Az-003 - кратерный тип разреза, Az031 - бортовой тип разреза в сравнении с нормальным типом разреза, вскрытым скважиной Az-007 (рис. 5).

Нормальный тип разреза. Изучен в соседней с кратером скважине Az-007 (рис. 5, 6). Детальная литологическая характеристика разреза рассмотрена авторами в публикации [Plyusnin, Gekche, 2020b]. Характеристика условий осадконакопления южной части НБА опубликована в статье [Plyusnin et al, 2020].

Разрез осадочного чехла начинается с верхненепской подсвиты (пачка 1), со стратиграфическим несогласием залегающей на фундаменте. Литологически она представлена глинисто-песчаными породами.

В строении тирской свиты наблюдается четкое разделение на подсвиты: нижнетирскую и верхнетирскую.

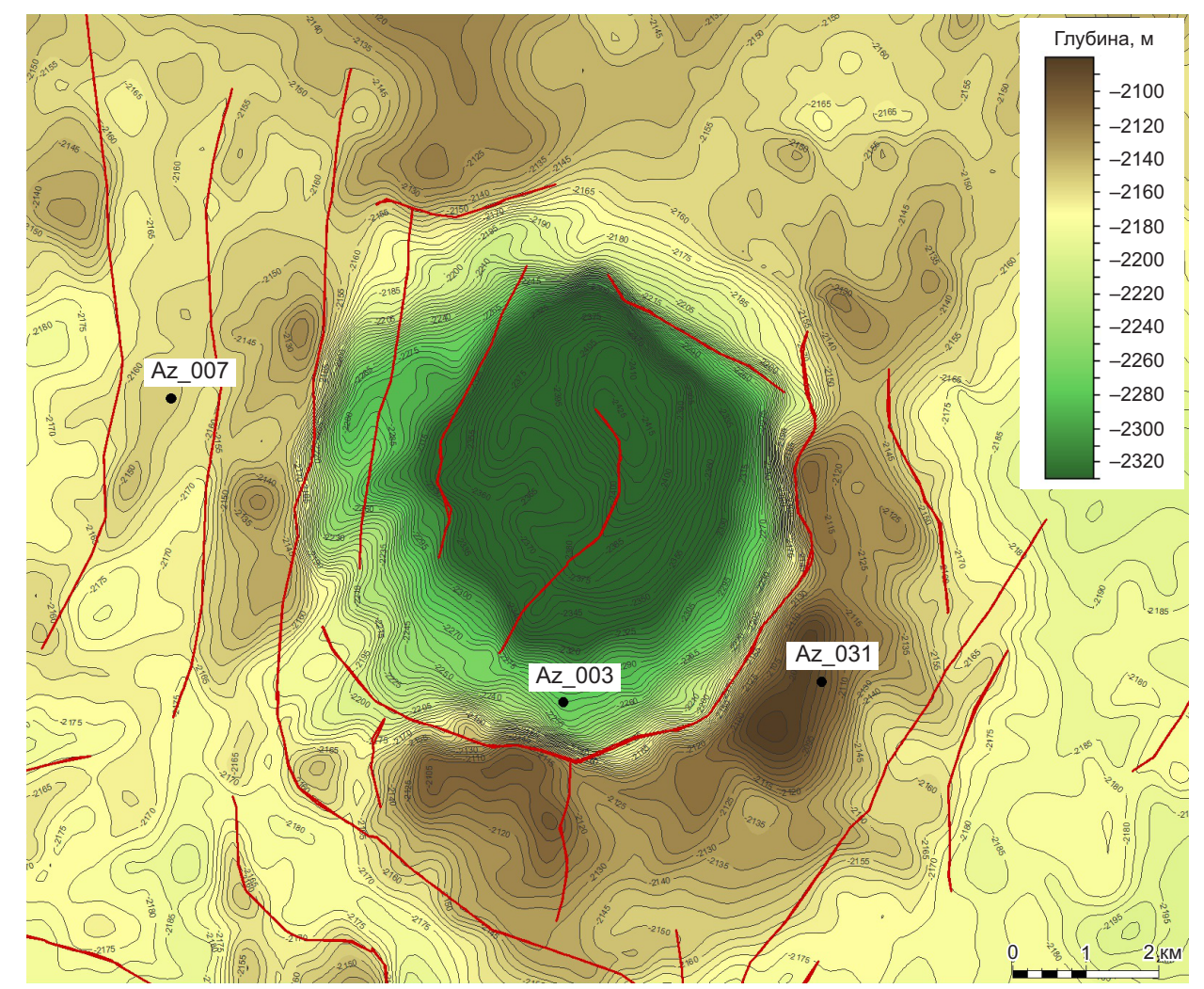

Рис. 2. Структурный план кровли фундамента района кратера Непский-1. Красными линиями показаны тектонические разломы, выделенные по результатам интерпретации сейсмики 3D. Точками отмечены изученные в работе скважины.

Fig. 2. Structural plan showing the basement roof in the area of the Nepsky-1 crater. Red lines - tectonic faults identified from the 3D seismic data. Dots - wells included in the study. 


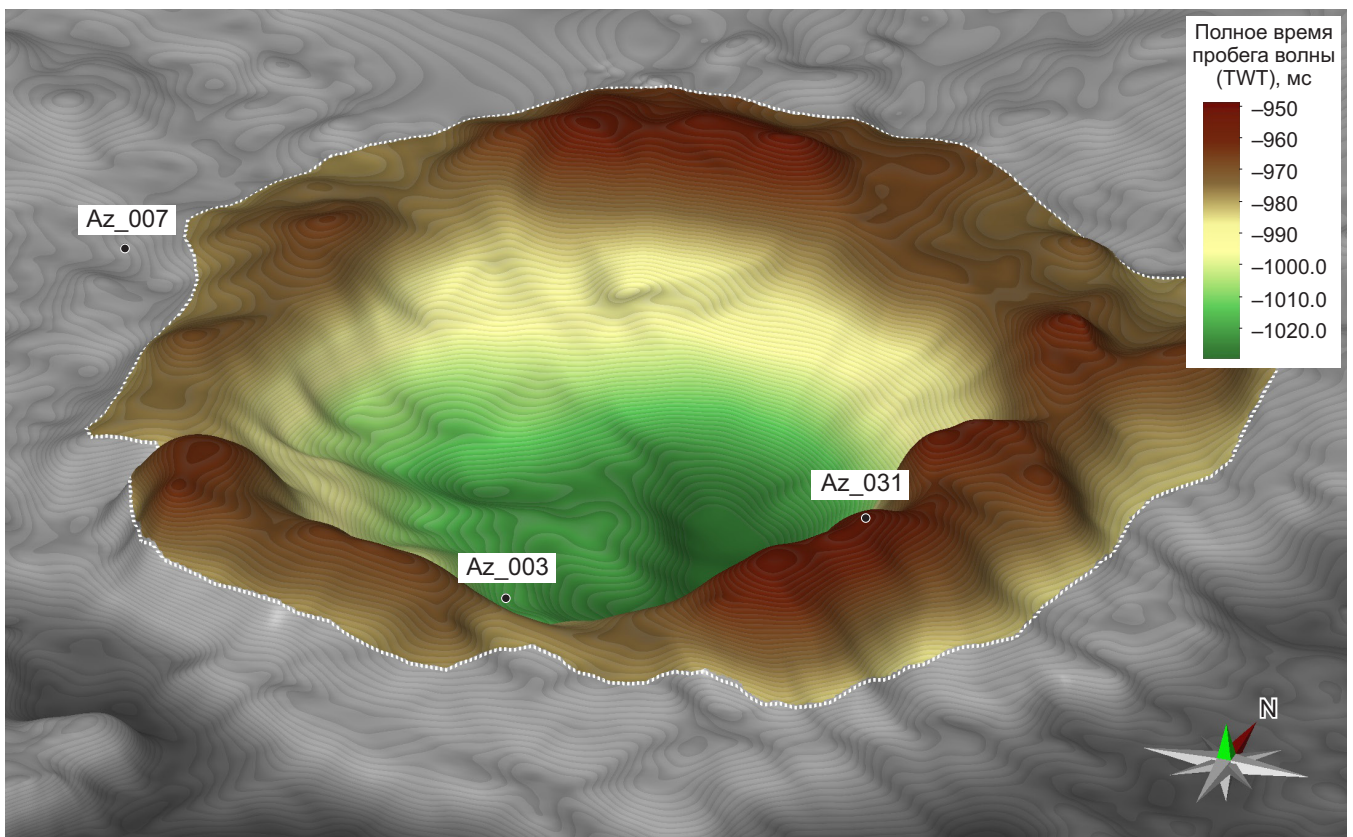

Рис. 3. Объемный вид на кратер по поверхности кристаллического фундамента. Построен по результатам интерпретации сейсмики 3D. Точками отмечены изученные в работе скважины.

Fig. 3. Three-dimensional view of the Nepsky-1 crater on the roof of the crystalline basement (based on the 3D seismic data). Dots wells included in the study.

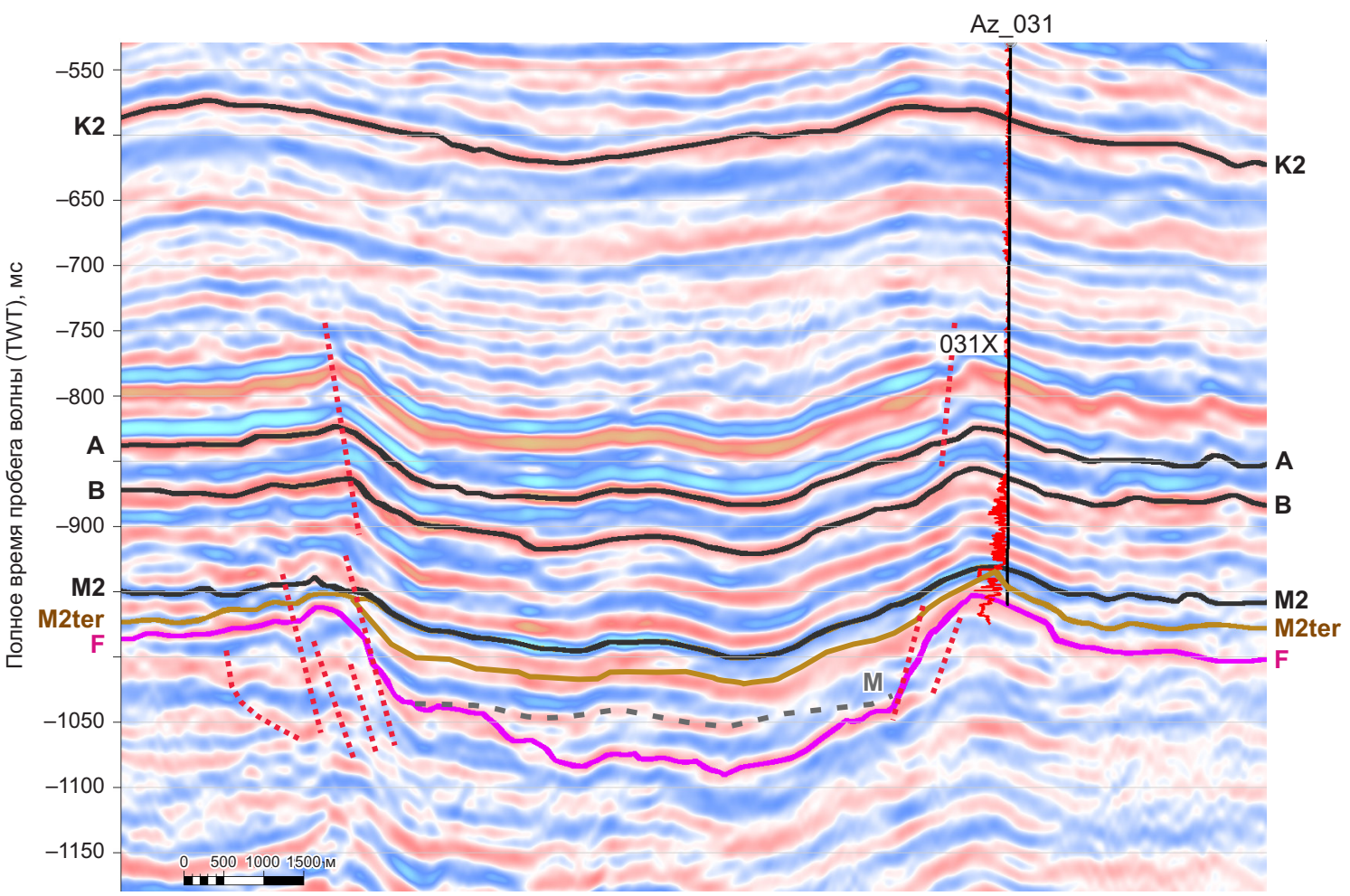

Рис. 4. Сейсмический разрез через кольцевую структуру.

Условные обозначения: F - поверхность кристаллического фундамента; M - поверхность плохо сортированных брекчиевидных пород, заполняющих кратер на начальных этапах осадконакопления; M2ter - кровля непского горизонта; М2 - кровля тирского горизонта; В - кровля даниловского горизонта; А - кровля средней осинской подсвиты усольской свиты усольского горизонта; К2 - кровля нижней подсвиты бельской свиты толбачанского горизонта.

Fig. 4. Seismic profile of the rim structure.

Legend: F - top of the crystalline basement; M - top surface of poorly sorted brecciated rocks that filled the crater at the initial stages of sedimentation; M2ter - top of the Nepian horizon; M2 - top of the Tirian horizon; B - top of the Danilov horizon; A - top of the middle Osinsky subsuite (Usolsky suite, Usolsky horizon); K2 - top of the lower Belsky subsuite (Tolbachan horizon). 
Нижнетирская подсвита со стратиграфическим несогласием перекрывает непскую свиту. В разрезе выделены две пачки: сульфатно-глинисто-песчаная (пачка 2) и сульфатно-глинисто-доломитовая (пачка 3).

Верхнетирская подсвита со стратиграфическим несогласием перекрывает нижнетирскую подсвиту. В разрезе выделены две пачки: глинисто-песчаная (пачка 4) и глинисто-сульфатно-карбонатная (пачка 5).

Кратерный тип разреза. Изучен на керне скважины Az-003. Для простоты повествования строения разреза авторами были выделены пачки. Отложения верхненепской подсвиты со стратиграфическим несогласием залегают на фундаменте (см. рис. 5, 6).

Пачка 1. По мощности в пачке преобладают доломиты - 80 \%, ангидриты - 20 \%. Доломиты светло-серые, микрокристаллические, с несохранившейся первичной структурой, с терригенной примесью до 5 \% (кварц и микроклин по данным петрографии), с конволютной слоистостью, плотные, неравномерно послойно сульфатизированные. Ангидриты голубовато-серые, яснокристаллические неравномерно доломитистые, от мелкодо крупножелваковых, плотные. Мощность доломитов от 0.09 до 0.50 м, ангидритов - от 0.02 до 0.20 м.

Пачка 2. Представлена единственным литотипом. Песчаники серые, разнозернистые, преимущественно средне- и мелкозернистые, с многочисленными полимиктовыми обломками - до 5 \% (обломки пород: слюдистые сланцы, кварциты; ксенолиты сложены карбонатами, кремнисто-слюдистым материалом); неяснослоистые, участками с оползневыми текстурами, плотные, пиритизированные. Обломки пород как окатанные, так и остроугольные, размер обломков варьируется в широком диапазоне - от гравийной до галечной размерности.

Разрыв долбления 2199-2244 м. В этом интервале, по данным гамма-каротажа и нейтронного каротажа, прогнозируется песчаный разрез с прослоями алевролитов.

Пачка 3. Представлена ритмичным переслаиванием трех основных литотипов алевролитов, тонко- и мелкозернистых песчаников. Алевролиты глинистые, крупно- и мелкозернистые, с тонкими слойками песчаника светло-серого, тонкозернистого и редкими слойками аргиллита темно-серого, с пологой, волнистой и конволютной слоистостью, плотные. Мощность литотипа от 0.02 до 0.10 м. Песчаники серые, полевошпат-кварцевые, разнозернистые, преимущественно тонкозернистые, хорошо отсортированные, с мелкой косой, пологоволнистой и конволютной слоистостью, пористые. Мощность литотипа от 0.05 до 0.5 м. Песчаники серые, разнозернистые, преимущественно мелкозернистые, с косой, пологоволнистой и конволютной слоистостью, с включениями литокластов карбонатного материала, пористые. Мощность литотипа от 0.05 до 1.50 м.

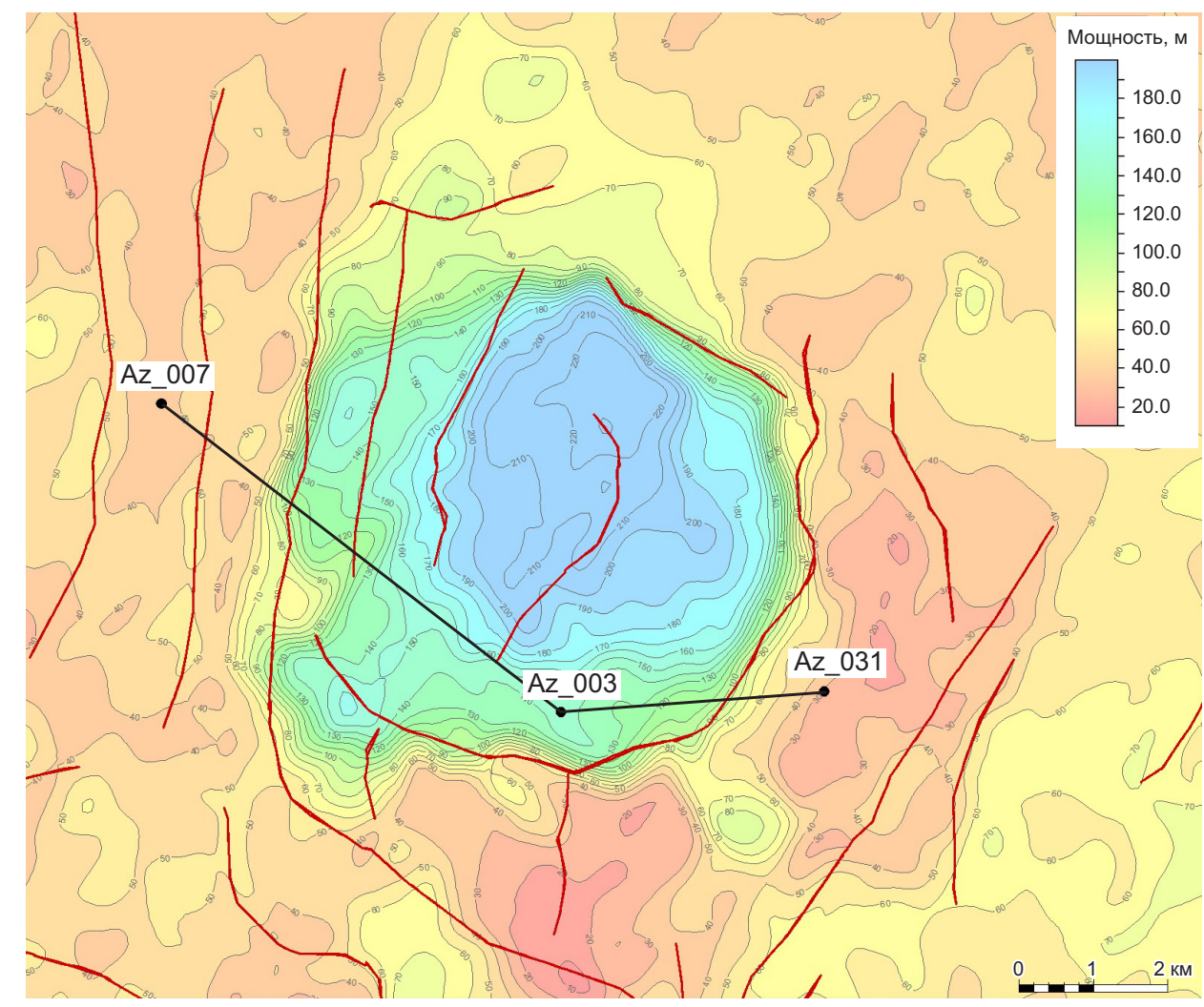

Рис. 5. Карта мощности терригенных отложений венда в районе кратера Непский-1 с линией профиля построения по изученным скважинам. Построена по результатам интерпретации сейсмики $3 \mathrm{D}$.

Fig. 5. Thickness of the Vendian terrigenous sediments in the area of the Nepsky-1 crater. The map is based on the 3D seismic data. The line of the profile using the well data is shown. 
Элементарные циклиты построены на уменьшение зернистости вверх. В подошве песчаники мелкозернистые, выше переходящие в песчаники тонкозернистые и алевролиты со слабоволнистой и пологой слоистостью. Мощность циклитов от 0.9 до 4.0 м.
Таким образом, разрез верхненепской подсвиты представлен преимущественно песчаниками. Снизу вверх по разрезу наблюдается улучшение окатанности и сортировки зерен песчаников. Содержание кварца, по данным петрографии, варьируется от 51 до 86 \%; полевых

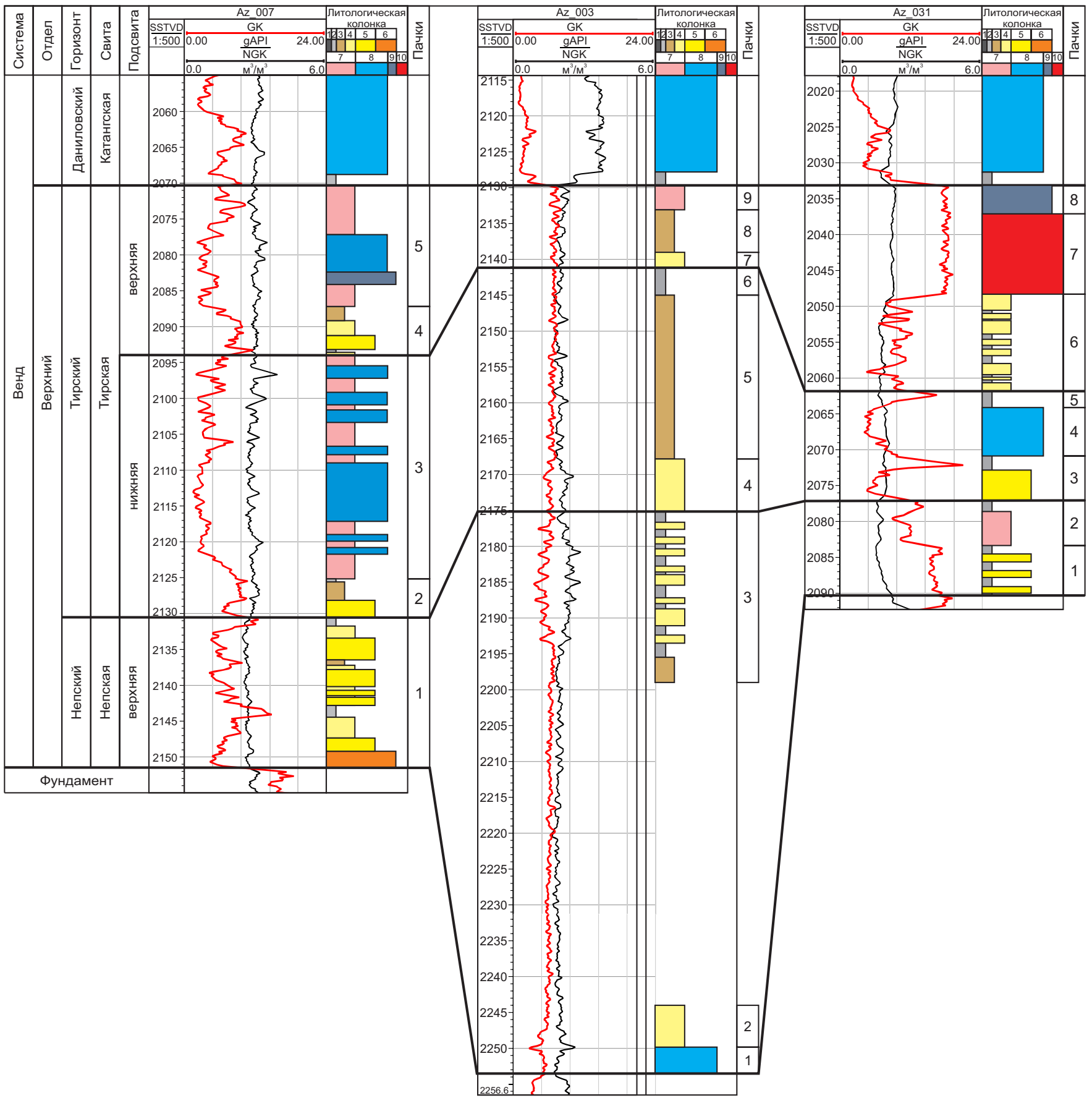

Рис. 6. Схема корреляции скважин через Непский кратер.

Скважины: Az-007 - нормальный тип разреза, Az-003 - кратерный тип разреза, Az-031 - бортовой тип разреза. Литологическая колонка: 1 - аргиллиты; 2 - алевролиты; 3 - тонкозернистые песчаники; 4 - мелкозернистые песчаники; 5 - среднезернистые песчаники; 6 - крупнозернистые песчаники; 7 - сульфатно-карбонатные породы; 8 - доломиты; 9 - мергель; 10 гранитная брекчия.

Fig. 6. Well correlation diagram for the Nepsky-1 crater.

Wells: Az-007 - normal section; Az-003 - crater section; Az-031 - rim section. Lithological column: 1 - mudstone (argillite); 2 - siltstone (aleurolite); 3 - fine-grained sandstone; 4 - small-grained sandstone; 5 - medium-grained sandstone; 6 - coarse-grained sandstone; 7 - sulfate-carbonate rock; 8 - dolomite; 9 - marl; 10 - granite breccia. 
шпатов (ортоклаз, микроклин, плагиоклаз) - от 3 до $9 \%$; обломки пород (преобладают глинистые сланцы и кварцит) от 2 до 5; содержание слюд (биотит и мусковит) до 5 \%. В терригенных породах преобладает доломитовый, сульфатный и глинистый цемент - от 10 до $49 \%$.

Накопление пачки 1 происходило в условиях озерной лагуны с переменной соленостью, в которую активно поступал терригенный и обломочный материал с внутренних бортов кратера в результате выветривания. На доломитах эрозионно залегают песчаники пачки 2, представляющие собой дистальную часть коллювиальных отложений, которые выносились стекающими с бортов кратера реками. Реки в кратере формировали озерные дельты. Кратер постепенно заполнялся обломочным кластическим материалом. Отложения пачки 3 формировались в условиях нижнего фронта дельты.

Отложения нижнетирской подсвиты со стратиграфическим несогласием перекрывают отложения верхненепской подсвиты.

Пачка 4. В разрезе пачки по мощности преобладают песчаники - 73 \%, алевролиты - $27 \%$. Песчаники серые и коричневато-серые, разнозернистые (от мелко- до тонкозернистых), преимущественно мелкозернистые, с пологонаклонной и волнистой слоистостью, подчеркнутой частыми тонкими слойками глинистого материала, с редкими интракластами алевролита от $0.02 \times 0.03$ мм до $0.08 \times 0.04$ см, плотные, с идентичными мелкими желвачками сульфатов. Мощность литотипа от 0.09 до 1.80 м. Алевролиты зеленовато-серые, крупно- и мелкозернистые, микро- и тонкослоистые, плотные. Мощность литотипа от 0.09 до 1.80 м.

Элементарные циклиты построены на уменьшение зернистости вверх. В подошве песчаники тонкомелкои мелкозернистые, выше переходящие в песчаники мелкотонко- и тонкозернистые, алевритистые с тонкой слоистостью, подчеркнутой прожилками и прослоями алевролита, которые закономерно увеличиваются к кровле циклита. Мощность циклитов от 1 до 3 м.

Пачка 5. По мощности в разрезе преобладают песчаники - $61 \%$, алевролиты - $39 \%$. Песчаники коричневато-серые, разнозернистые (от мелко- до тонкозернистых), преимущественно тонкозернистые, с тонкими слойками алевролита и глинисто-битуминозного материала мощностью до 0.005 м; с косой, пологой и волнистой слоистостью, участками с конволютной слоистостью, плотные, с единичными включениями желваков ангидрита. Мощность литотипа от 0.09 до 1.80 м. Алевролиты глинистые, зеленовато-серые, крупно- и мелкозернистые, микро- и тонкослоистые, плотные. Мощность литотипа от 0.09 до 1.80 м.

Элементарные циклиты построены на уменьшение зернистости вверх. В подошве песчаники мелкозернистые с косой и срезанной слоистостью, с угловатоокатанными интракластами алевролита размером до $0.02 \times 0.05$ м, выше переходящие в песчаники от тонкомелко- до мелкотонкозернистых с мелкой косой и пологой волнистой слоистостью, участками с прожилками и прослоями алевролита, количество которых возрастает к кровле циклита. Мощность циклитов от 0.5 до $7.0 \mathrm{M}$.

Пачка 6. В разрезе по мощности преобладают алевролиты - 70 \%, доломиты - 20 \% и песчаники - $10 \%$. Алевролиты серые, мелко- и крупнозернистые, глинистые, с пологой и линзовидно-волнистой слоистостью, плотные. Мощность литотипа от 0.5 до 5.0 м. Песчаники серые, разнозернистые (от мелкотонкозернистых до тонкозернистых), с мелкой косой и конволютной слоистостью, пористые. Мощность литотипа от 0.05 до 0.40 м. Доломиты серые, микрокристаллические, с несохранившейся первичной структурой, с тонкими слойками аргиллита и глинисто-битуминозного материала, плотные, сульфатизированные с округлыми стяжениями ангидрита белого яснокристаллического. Мощность литотипа от 0.09 до 0.30 м. В подошве элементарного циклита залегают песчаники, выше переходящие в алевролиты и доломиты. Контакты между песчаником и нижележащими доломитами эрозионные. Мощность циклитов от 1.5 до 5.0 м.

Таким образом разрез нижнетирской подсвиты представлен песчано-глинистыми породами с прослоями сульфатизированных доломитов. Песчаники, в целом, хорошо окатанные и отсортированные. Содержание кварца, по данным петрографии, варьируется от 82 до 95 \%, полевых шпатов (ортоклаз, микроклин) - от 4 до 15 \%, обломки пород (кварцит) до 3, содержание слюд (мусковит и биотит) до 1 \%. В терригенных породах преобладает доломитовый, галитовый, сульфатный и глинистый цемент - от 6 до $27 \%$.

Как было показано ранее, на этапе низкого стояния уровня моря вдоль юго-восточной части НБА происходило формирование аллювиальных и дельтово-баровых отложений, к которым приурочен парфеновский продуктивный горизонт [Plyusnin, Gekche, 2020b]. Haкопление пачек 4 и 5 происходило в условиях нижнего фронта дельты. По мере уменьшения привноса терригенного материала в кратер и общей трансгрессии происходил переход от дельтовых в приливно-отливные и более спокойные лагунные условия осадконакопления. В это время накапливалась пачка 6, в строении которой отразилась сезонность трансгрессивно-регрессивных микроциклов.

Отложения верхнетирской подсвиты со стратиграфическим несогласием перекрывают отложения верхненепской подсвиты.

Пачка 7. В разрезе по мощности преобладают песчаники - 60 \%, алевролиты - 20 \%, доломиты - 20 \%. Песчаники коричневато-серые, мелкозернистые, с косой и линзовидно-волнистой слоистостью, участками с конволютной слоистостью, пористые. Мощность литотипа от 0.09 до 1.20 м. Алевролиты глинистые, серые, крупнозернистые, с частыми тонкими слойками аргиллита серо-зеленого, с пологоволнистой слоистостью, плотные. Мощность литотипа от 0.02 до 0.20 м. Доломиты сульфатизированные, темно-серые, микрокристаллические 
с несохранившейся первичной структурой, с примесью терригенного материала, пористые, с мелкими включениями ангидрита яснокристаллического. Мощность литотипа от 0.05 до 0.45 м.

В подошве элементарного циклита залегают песчаники, переходящие в алевролиты и перекрытые доломитами. Контакты между песчаником и нижележащими доломитами эрозионные. Мощность циклитов от 0.5 до $1.0 \mathrm{M}$.

Пачка 8. В разрезе по мощности преобладают алевролиты - 75 \%, песчаники - $10 \%$, доломиты - $10 \%$, аргиллиты - 5 \%. Аргиллиты темно-серого цвета, алевритистые, микрослоистые, плотные. Мощность литотипа от 0.01 до 0.10 м. Алевролиты глинистые, серые, крупно- и мелкозернистые, с тонкой полого- и слабоволнистой слоистостью, плотные. Мощность литотипа от 0.09 до 0.94 м. Песчаники серые, от тонко- до мелкозернистых, с прерывистой и волнистой слоистостью, тонкопористые. Мощность литотипа от 0.10 до $0.44 \mathrm{M}$. Доломиты светло-серые, микрокристаллические, с несохранившейся первичной структурой, плотные, неравномерно сульфатизированные и окремненные. Мощность литотипа от 0.1 до $0.3 \mathrm{M}$.

В подошве элементарного циклита залегают песчаники, выше перекрывающиеся алевролитами, аргиллитами и доломитами. Мощность циклитов от 0.6 до $2.0 \mathrm{M}$.

Пачка 9. Пачка представлена единственным литотипом. Доломиты глинистые, светло-серые, микрокристаллические, с несохранившейся первичной структурой, с тонкими слойками глинисто-битумного материала, плотные, слабо сульфатизированные, с единичными желваками ангидрита голубовато-серого яснокристаллического.

Таким образом, разрез верхнетирской подсвиты представлен песчано-глинистыми породами с прослоями неравномерно сульфатизированных доломитов. Песчаники хорошо окатанные и отсортированные. Содержание кварца, по данным петрографии, варьируется от 90 до 98 \%, полевых шпатов (ортоклаз, плагиоклаз) от 3 до $9 \%$; обломки пород (кварцит) до 3; содержание слюд (мусковит и биотит) до 3 \%. В терригенных породах преобладает доломитовый, галитовый, сульфатный и глинистый цементы от - 2 до $10 \%$.

Накопление пачки 7 происходило в условиях фронта дельты. На этапе низкого стояния уровня моря происходило формирование аллювиальных и дельтовых отложений, к которым приурочен верхнетирский продуктивный горизонт. По мере уменьшения привноса терригенного материала и общей трансгрессии произошла смена условий осадконакопления на прибрежно- (пачка 8) и мелководно-морские (пачка 9).

В целом озерные условия были благоприятны для накопления органического вещества, которое присутствует в поровом, микропоровом, микротрещинном и межкристаллическом пространстве пород изученной скважины. Результаты пиролитических исследований подтверждают высокий генерационный потенциал.
Таким образом, уникальность кратерного типа разреза заключается как в повышенных мощностях терригенных отложений, так и в высоком содержании органического вещества. Можно предполагать наличие нефтематеринских пород в кратерном типе разреза.

Бортовой тип разреза. Изучен на керне скважины Az-031, которая находится на внешней части склона аллогенной брекчии (см. рис. 5, 6). Разрез осадочного чехла начинается с верхненепской подсвиты, со стратиграфическим несогласием залегающей на фундаменте. В разрезе выделено две пачки.

Пачка 1. Представлена переслаиванием алевролитов коричневато-серых, крупнозернистых, плотных и песчаников серых, крупнозернистых, с многосильными угловатыми обломками гранита гравийной и валунной размерности, беспорядочно-слоистых, пористых.

Пачка 2. Представлена глинисто-сульфатно-карбонатными плотными породами. Накопление осадочного материала происходило после выравнивания окружающего кратер рельефа с уровнем склона аллогенной брекчии. Отмечается влияние оползневых склоновых процессов. Углы падения слоев песчаников составляют $75^{\circ}$ (пачка 1). Возможно, они могли формировать террасы. Позднее возникли благоприятные условия для формирования на данных террасах небольших озер, которые под действием аридного климата активно испарялись и оставляли после себя глинисто-сульфатнокарбонатные отложения. В разрезе нижнетирской подсвиты выделено три пачки.

Пачка 3. В основании залегают песчаники серые, крупнозернистые, косослоистые, пористые. В верхней части алевролиты серые, крупнозернистые, тонкослоистые, плотные. Отмечаются углы падения слоев песчаников в 60-70.

Пачка 4. Доломиты серые, микрокристаллические, с несохранившейся первичной структурой, плотные.

Пачка 5. Алевролиты серые, мелкозернистые, микрослоистые, плотные. В разрезе верхнетирской подсвиты выделено три пачки.

Пачка 6. Представлена переслаиванием алевролитов коричневато-серых, волнисто-слоистых, плотных и песчаников серых, мелкозернистых, косослоистых, пористых.

Пачка 7. Представлена обломками гранита глыбово-щебенчатой размерности.

Пачка 8. Доломиты глинистые, светло-серые, микрокристаллические, с несохранившейся первичной структурой, плотные.

Накопление нижне- и верхнетирских отложений происходило циклично. По мере выравнивания рельефа все меньшее влияние оказывали склоновые процессы.

Таким образом, метеорный кратер, образованный до непского времени, создал уникальный тип разреза повышенной мощности. В непское время в него происходила разгрузка рек, формирующих озерные дельты. В тирское время на этапе низкого стояния уровня моря происходило формирование небольших дельт, время существования которых было ограничено 
началом трансгрессии моря. Постепенно на месте кратера накапливались смешанные карбонатно-терригенные осадки.

В позднетирское время, по мнению авторов, произошла тектоническая активизация, которая привела к выводу в субаэральные условия отложения в кратере и спровоцировала частичное разрушение выступов аллогенной брекчии, которые сформировали выносы (пачка 7) в бортовом типе разреза. Это видно по сокращению мощности верхнетирских отложений в кратерном типе разреза по сравнению с соседними скважинами на корреляционном профиле, выравненном на региональный репер - подошву даниловского горизонта (рис. 6). Не исключено, что данная активизация сопровождалась землетрясениями, так как только сочетание выветривания и землетрясения могло спровоцировать разрушение выступающих частей валов аллогенной брекчии.

\section{6. ЗАКЛЮЧЕНИЕ}

Таким образом, авторами впервые приводится детальное описание погребенного импактного кратера на поверхности фундамента Непско-Ботуобинской антеклизы. Наличие кратера свидетельствует о бомбардировке космическими объектами Сибирского палеоконтинента в докембрии. Благодаря импактному воздействию образовался специфический тип разреза непской и тирской свиты, который был впервые описан авторами. Мощность непских отложений превышена в четыре раза, в отличие от таковых за пределами кратера. Равномерное поступление осадочного материала, наличие относительно спокойных озерных условий в сочетании с восстановительной геохимической средой создали благоприятные условия для формирования нефтематеринских пород, что делает обнаружение таких структур актуальным. Выявление кратеров является перспективной задачей нефтегазовой отрасли.

Формирование отложений контролировалось колебанием уровня моря. К песчаникам, накопившимся в этап низкого стояния уровня моря, приурочены основные терригенные продуктивные горизонты. Перерывы в осадконакоплении связаны с падением уровня моря. Анализ керна из кратерного типа разреза показал, что в позднетирское время имела место активизация, приведшая к росту тектонически активных структур примерно на 15-20 м с образованием в бортовом типе разреза конуса выноса с обломками гранита. Таким образом, впервые на территории НБА зафиксирован факт влияния тектонических положительных вертикальных движений на осадконакопление. В непское и тирское время, по мнению авторов, происходили тектонические события, инициировавшие относительно быстрое выветривание и транспортировку материала, которые еще предстоит изучить.

\section{7. ЛИТЕРАТУРА/REFERENCES}

Bacon M., Simm R., Redshaw T., 2007. 3-D Seismic Interpretation. Cambridge University Press, Cambridge, 236 p.
Belyaev S.Yu., Moiseev S.A., Titov D.Yu., 2009. Tectonic Development of the Nepa-Botuoba Anteclise in Vendian and Cambrian. In: Geodynamic Evolution of the Lithosphere of the Central Asian Mobile Belt (From Ocean to Continent). Proceedings of the Scientific Meeting on the Basic Research Programme, Earth Sciences Section RAS (October 11-14, 2009). Vol. 7. IEC SB RAS, Irkutsk, p. 32-34 (in Russian) [Беляев С.Ю., Моисеев С.А., Титов Д.Ю. Тектоническое развитие НепскоБотуобинской антеклизы в венде и кембрии // Геодинамическая эволюция литосферы Центрально-Азиатского подвижного пояса (от океана к континенту): Материалы научного совещания по Программе фундаментальных исследований ОНЗ РАН (11-14 октября 2009 г.). Иркутск: ИЗК СО РАН, 2009. Вып. 7. С. 32-34].

Collins G.S., Melosh H.J., Marcus R.A, 2005. Earth Impact Effects Program: A Web- Based Computer Program for Calculating the Regional Environmental Consequences of a Meteoroid Impact on Earth. Meteoritics \& Planetary Science 40 (6), 817-840. https://doi.org/10.1111/j.1945-5100. 2005.tb00157.x.

Earth Impact Database, 2018. Available from: http:// passc.net/EarthImpactDatabase.

Fel'dman V.I., Glazovskaya L.I., 2018. Impactite Genesis. Text Book. University Book House, Moscow, 151 p. (in Russian) [Фельдман В.И., Глазовская Л.И. Импактитогенез: учебное пособие. М: Книжный дом «Университет», 2018. 151 c.].

Glukhovsky M.Z., Kuz'min M.I., 2015. Extraterrestrial Factors and Their Role in the Tectonic Evolution of the Earth in Early Precambrian. Russian Geology and Geophysics 56 (7), 1225-1249 (in Russian) [Глуховский М.З., Кузьмин М.И. Внеземные факторы и их роль в тектонической эволюции Земли в раннем докембрии // Геология и геофизика. 2015. Т. 56. № 7. С. 1225-1249].

Gurov E.P., 2016. Impact Structures in Seas and Oceans. Geology and Mineral Resources of the World Ocean 1, 5-18 (in Russian) [Гуров Е.П. Импактные структуры в морях и океанах // Геология и полезные ископаемые Мирового океана. 2016. № 1. С. 5-18].

Gurov E.P., Gozhik P.F., 2006. Impact Cratering in the Earth History. Naukova Dumka, Kiev, 216 p. (in Russian) [Гуров Е.П., Гожик П.Ф. Импактное кратерообразование в истории Земли. Киев: Наукова думка, 2006. 216 с.].

Kuznetsov V.G., 2011. Lithology. Foundations of General (Theoretical) Lithology. Nauchny Mir, Moscow, 360 p. (in Russian) [Кузнецов В.Г. Литология: Основы общей (теоретической) литологии. М.: Научный мир, 2011. 360 c.].

Mazur M.J., Stewart R.R., Hildebrand A.R, 2000. The Seismic Signature of Meteorite Impact Craters. CSEG Recorder 25 (6), 10-16.

Mel'nikov N.V., 2009. Vendian-Cambrian Salt-Bearing Basin of the Siberian Platform (Stratigraphy, and History of Development). Publishing House of SB RAS, Novosibirsk, 148 p. (in Russian) [Мельников Н.В. Венд-кембрийский солеродный бассейн Сибирской платформы (стратиграфия, история развития). Новосибирск: Изд-во СО PAH, 2009. 148 c.]. 
Mel'nikov N.V., Repina L.N. (Eds), 1989. Decisions of the Fourth Interdepartmental Regional Stratigraphic Meeting on Refining and Supplementing the Vendian and Cambrian Stratigraphic Schemes of the Inner Siberian Platform. SNIIGGiMS, Novosibirsk, 64 p. (in Russian) [Решения Четвертого межведомственного регионального стратиграфического совещания по уточнению и дополнению стратиграфических схем венда и кембрия внутренних районов Сибирской платформы / Ред. Н.В. Мельников, Л.Н. Репина. Новосибирск: СНИИГГиМС, 1989. 64 с.].

Mikheeva A.V., 2008. New Data from the Catalogue of Impact Structures of the Earth. In: The 100 Years Anniversary of the Fall of the Tunguska Meteorite (Relay Race of Generations). Materials of the All-Russia Scientific and Applied Conference (June 26-30, 2008). IPK SFU, Krasnoyarsk, 290-300 (in Russian) [Михеева A.В., 2008. Новые данные каталога «Импактные структуры Земли» // 100 лет падению Тунгусского метеорита (эстафета поколений): Материалы Всероссийской научно-практической конференции (26-30 июня 2008 г.). Красноярск: ИПК СФУ, 2008. C. 290-300]. http://elib.sfu-kras.ru/handle/2311/8592.

Mikheeva A.V., 2020. The Complete Catalog of the Earth's Impact structures. ICMMG SB RAS, 2020 (in Russian) [Михеева А.В. Полный каталог импактных структур Земли. ИВМиМГ СО РАН, 2020]. http://labmpg.sscc.ru/ (Дата последнего обращения 03.03.2020).

Naldrett A.J., 2003. From Impact to Riches: Evolution of geological understanding as seen at Sudbury, Canada. GSA Today 13 (2), 4-9. https://doi.org/10.1130/1052-5173(20 03) $013<0004$ :FITREO>2.0.CO;2.

Plyusnin A.V., Gekche M.I., 2020a. The First Data on the Discovery of an Impact Structure on the Basement Roof of the Southern Part of the Siberian Platform (Nepsky-1 Crater). In: Fundamental Problems of Geotectonics and Geodynamics. Proceedings of the LII Tectonic Meeting (January 28 - February 01, 2020). GEOS, Moscow, 157-161 (in Russian) [Плюснин A.В., Гёкче М.И. Первые данные об обнаружении импактной структуры на поверхности фундамента юга Сибирской платформы (кратер Непский-1) // Фундаментальные проблемы геотектоники и геодинамики: Материалы LII тектонического совещания (28 января 01 февраля 2020 г.). М.: ГЕОС, 2020. С. 157-161].
Plyusnin A.V., Gekche M.I., 2020b. Composition and Structure of the Nepa and Tira Suites of the Prilensky-Nepa Structural Facies Zone of the Nepa-Botuoba Anteclise Based on Core Study Results. Proceedings of Higher Educational Establishments. Geology and Exploration 2, 75-89 (in Russian) [Плюснин А.В., Гёкче М.И. Состав и строение непской и тирской свиты Приленско-Непской структурнофациальной зоны Непско-Ботуобинской антеклизы по результатам изучения кернового материала // Известия высших учебных заведений. Геология и разведка. 2020. №2. C. 75-89]. https://doi.org/10.32454/0016-77 62-2020-63-1-75-89.

Plyusnin A.V., Ibragimov R.R., Gekche M.I., 2020. The History of Geological Development of the Southern Part of the Nepa-Botuoba Anteclise in the Nepa and Tira Times. Oil Industry 9, 21-25 (in Russian) [Плюснин А.В., Ибрагимов Р.Р., Гёкче М.И. История геологического развития юга Непско-Ботуобинской антеклизы в непское и тирское время // Нефтяное хозяйство. 2020. № 9. С. 21-25]. https://doi.org/10.24887/0028-2448-2020-9-21-25.

Posamentier H.W., Allen G.P., 1999. Siliciclastic Sequence Stratigraphy - Concepts and Applications. SEPM Concepts in Sedimentology and Paleontology Series 7, 210 p.

Reinek G.E., Singkh I.B., 1981. Setting of Terrigenous Sedimentation. Nedra, Moscow, 440 p. (in Russian) [Рейнек Г.Э., Сингх И.Б. Обстановки терригенного осадконакопления. М.: Недра, 1981. 440 с.].

Tectonic Map of Petroleum Provinces of the Siberian Platform, 2005. Scale 1:5000000. SNIIGGiMS Publishing House, Novosibirsk (in Russian) [Тектоническая карта нефтегазоносных провинций Сибирской платформы. Масштаб 1:5000000. Новосибирск: Изд-во СНИИГГиМС, 2005].

Tsikalas F., Faleide J.I., 2007. Post-impact Structural Crater Modification Due to Sediment Loading: An Overlooked Process. Meteoritics \& Planetary Science 42 (11), 2013-2029. https://doi.org/10.1111/j.1945-5100.2007.tb00557.x.

Wieland F., Gibson R.L., Reimold W.U., 2005. Structural Analysis of the Collar of the Vredefort Dome, South Africa Significance for Impact-Related Deformation and Central Uplift Formation. Meteoritics \& Planetary Science 40 (9-10), 1537-1554. https://doi.org/10.1111/j.1945-5100.2005. tb00416.x. 